\title{
Nocardia dassonvillei, a Macroscopic Replica of Streptomyces griseus
}

\author{
By RUTH E. GORDON AND ANN C. HORAN \\ Institute of Microbiology, Rutgers, The State University, \\ New Brunswick, New Jersey, U.S.A.
}

(Accepted for publication I8 July 1967)

\begin{abstract}
SUMMARY
Twenty-six strains of Nocardia dassonvillei (Brocq-Rousseu) Liégard \& Landrieu from the soil and from infections of man and animals are described, and a pattern of characteristics for their identification and differentiation from $N$. asteroides, $N$. brasiliensis, $N$. caviae, $N$. madurae and $N$. pelletieri is presented. Strains of $N$.dassonvillei resembled strains of Streptomyces griseus (Krainsky) Waksman \& Henrici in the macroscopic appearance of their growth and in many of the physiological properties examined.
\end{abstract}

\section{INTRODUCTION}

The strains of nocardias and streptomycetes examined by Becker, Lechevalier, Gordon \& Lechevalier (1964) for the form of diaminopimelic acid (DAP) in hydrolysates of whole organisms included a small group isolated from pulmonary infections of animals in the Chicago Zoological Park. The strains of this group macroscopically resembled strains of Streptomyces griseus, and two strains had the same pattern of physiological characteristics as $S$. griseus. Only two properties, at that time, separated the others from $S$. griseus. Later Becker et al. (1964) reported that the two strains had the $L L$-form of DAP and the other strains the meso-form. Determination of the form of DAP was therefore added to our observations of those nocardias and streptomycetes in our collection of whose specific identity we were uncertain.

Strains from other sources were encountered with the three correlating properties that distinguished them from Streptomyces griseus, and only one more property was found to widen the separation between the two taxa. Because the strain bearing the oldest name among those with the meso-form of DAP was Nocardia dassonvillei (Brocq-Rousseu, 1907) Liégard \& Landrieu (I9II), we assigned this name to the group. A pattern of characteristics for the recognition of strains of $N$. dassonville $i$ is given here and contrasted with the properties of $S$. griseus and those of five other species of Nocardia.

\section{METHODS}

Organisms. The strains presented in Table I were compared with those listed by Gordon \& Horan (I968) and by Gordon (I966).

Tests. The strains were examined according to the procedures described by Gordon (1966, 1967), and for the the form of diaminopimelic acid (Becker et al. 1964). 


\section{RESULTS}

Smears of the 26 cultures of Nocardia dassonvillei, grown on glycerol agar for 5 days and stained by a modified Ziehl-Neelsen method, showed long filaments. Approximately half the smears also contained rods of varying lengths and a few coccoid bodies. The cultures were not acid-fast.

\section{Table I. Strains identified as Nocardia dassonvillei}

\begin{tabular}{|c|c|}
\hline Strain no. & Name when received, source, strain name or number \\
\hline 509 & $\begin{array}{l}\text { * Nocardia dassonvillei (Brocq-Rousseu) Liégard \& Landrieu; P. Thibault, } \\
\text { Inst. Pasteur, Paris }\end{array}$ \\
\hline N 3255 & Nocardia madurae; (NCTC 3255$)$ \\
\hline 575 & $\begin{array}{l}\text { Nocardia sp.; C. W. Emmons, Nat. Inst. of Health, Bethesda, Md. (A 826); } \\
\text { G. Altmann (1 } 344 \text {, ulcerating lesion on leg of patient with elephantiasis) }\end{array}$ \\
\hline $639,711,714-718$ & $\begin{array}{l}\text { Nocardia sp.; E. B. Tilden, Chicago Zoological Park, Brookfield, Ill. (lung } \\
\text { lesion of a sitatunga; P 2, lung of a penguin; } 6,9,10,11,12 \text {, lung of a } \\
\text { kangaroo) }\end{array}$ \\
\hline I 288 & Nocardia sp.; C. W. Emmons (10,006, nasal washings) \\
\hline 1289 & $\begin{array}{l}\text { Nocardia sp.; N. F. Conant, Duke Univ.; H. A. Campana (Malloch, chronic } \\
\text { ulcer following bite of a dog) }\end{array}$ \\
\hline $1322-1330$ & $\begin{array}{l}\text { Nocardia spp.; M. P. Lechevalier, Rutgers Univ. (G I, G 2, H I, J 2, J 3, } \\
\text { L Io, L I 3, I I-36, soil; Cross Fil., bovine streptothricosis) }\end{array}$ \\
\hline N434 & Streptomyces listeri (Erikson) Waksman \& Henrici; NCTC; (434, human) \\
\hline 1236 & Streptomyces sp.; C. W. Emmons (B-203I, pulmonary lymph node) \\
\hline 1250 & $\begin{array}{l}\text { † Streptomyces sp.; D. Taplin, Univ. of Miami (Babcock, case of erosive } \\
\text { plantar disease) }\end{array}$ \\
\hline 794 & $\begin{array}{l}\text { Unidentified isolation; H. Cohen, Kaiser Foundation Hosp., Los Angeles, } \\
\text { Calif. (Robinson, pleural biopsy) }\end{array}$ \\
\hline 1213 & $\begin{array}{l}\text { Unidentified isolation; G. Ryvarden, Kaiserin Elizabeth Hospital, Vienna } \\
\text { (venous blood of patient with malignant lymphoma) }\end{array}$ \\
\hline & $\begin{array}{l}* \text { ATCC } 23218 ; \text { NCTC } 10488 . \\
+ \text { ATCC } 23219 ; \text { NCTC } 10489 .\end{array}$ \\
\hline
\end{tabular}

Under the conditions of the examination, the 26 strains formed loosely or densely filamentous colonies; colonies with smooth margins were not observed. Aerial hyphae were not produced by four of the cultures and in the remaining cultures varied from sparse to abundant. These hyphae were short and straight, or long and branching, straight or coiled (Pl. I). Sporulation was abundant. The colonies of a few strains displayed many purple-coloured crystals identified by Gerber (I966) as crystals of iodinin.

Cultures grown on 'yeast dextrose (glucose) agar' were macroscopically abudant, coarsely wrinkled or flat. The growth was yellowish, greenish yellow or reddish brown, and produced a yellowish, greenish yellow or brown soluble pigment. The aerial hyphae formed by some cultures were not visible to the unaided eye but on other cultures showed as a sparse coating or a few whitish patches; still other cultures were thickly covered with greyish aerial hyphae. The resemblance of cultures of Nocardia dassonvillei to cultures of Streptomyces griseus is illustrated in PI. 2.

The 26 strains of Nocardia dassonvillei in our collection dissolved adenine, casein, hypoxanthine, tyrosine, and xanthine; did not grow at $45^{\circ}$ and $10^{\circ}$; utilized lactate, malate and succinate, but not mucate or oxalate; were sensitive to lysozyme and salicylate; did not ferment glucose; hydrolysed hippurate and starch; formed acid from glucose, maltose, mannitol, and mannose; did not produce acid from adonitol, dulcitol, 
Table 2. Comparison of some reactions of Nocardia dassonvillei and of Streptomyces griseus

\begin{tabular}{|c|c|c|}
\hline \multirow[t]{2}{*}{ Property } & $\begin{array}{c}\text { Nocardia } \\
\text { dassonvillei } \\
\text { (26 strains) }\end{array}$ & $\begin{array}{c}\text { Streptomyce } \\
\text { griseus } \\
\text { (123 strains) }\end{array}$ \\
\hline & \multicolumn{2}{|c|}{ Positive strains $(\%)$} \\
\hline \multicolumn{3}{|l|}{ Decomposition of } \\
\hline Adenine & 100 & 98 \\
\hline Casein & 100 & 100 \\
\hline Hypoxanthine & 100 & 100 \\
\hline Tyrosine & 100 & 100 \\
\hline Urea & 35 & 97 \\
\hline Xanthine & IOO & 100 \\
\hline \multicolumn{3}{|l|}{ Growth at } \\
\hline $45^{\circ}$ & 0 & 0 \\
\hline $40^{\circ}$ & 80 & 33 \\
\hline $10^{\circ}$ & 0 & 100 \\
\hline Survival at $50^{\circ}$ for $8 \mathrm{hr}$ & 92 & 99 \\
\hline Nitrite from nitrate & 92 & 73 \\
\hline \multicolumn{3}{|l|}{ Utilization of } \\
\hline Citrate & 96 & 99 \\
\hline Lactate & 100 & 90 \\
\hline Malate & 100 & 100 \\
\hline Mucate & 0 & 0 \\
\hline Oxalate & 0 & 0 \\
\hline Succinate & 100 & 100 \\
\hline \multicolumn{3}{|l|}{ Resistance to } \\
\hline Lysozyme & 0 & $\mathbf{I}$ \\
\hline Salicylate & 0 & 2 \\
\hline Oxidation of glucose & 85 & 98 \\
\hline Fermentation of glucose & 0 & 0 \\
\hline \multicolumn{3}{|l|}{ Hydrolysis of } \\
\hline Hippurate & 100 & 5 \\
\hline Starch & 100 & 100 \\
\hline \multicolumn{3}{|l|}{ Acid from } \\
\hline Adonitol & 0 & 43 \\
\hline Arabinose & 60 & 63 \\
\hline Dulcitol & 0 & 0 \\
\hline Erythritol & 0 & $\mathbf{I}$ \\
\hline Galactose & 62 & 99 \\
\hline Glucose & 100 & 100 \\
\hline Inositol & 0 & 15 \\
\hline Lactose & 0 & 100 \\
\hline Maltose & 100 & 100 \\
\hline Mannitol & 100 & 97 \\
\hline Mannose & 100 & 100 \\
\hline Melibiose & $3 I$ & 0 \\
\hline$\alpha$-Methyl-D-glucoside & 23 & 98 \\
\hline Raffinose & 0 & 2 \\
\hline Rhamnose & 65 & 31 \\
\hline Sorbitol & 0 & 0 \\
\hline Trehalose & 65 & 99 \\
\hline Xylose & $8 \mathrm{I}$ & 100 \\
\hline Meso-diaminopimelic acid & 100 & $0^{*}$ \\
\hline$L L$-diaminopimelic acid & 0 & IOO* \\
\hline
\end{tabular}

* Twenty-one strains analysed. 
erythritol, inositol, lactose, raffinose or sorbitol; had the meso-form of DAP in hydrolysates of whole organisms (Table 2). Survival at $50^{\circ}$ for $8 \mathrm{hr}$, reduction of nitrate to nitrite, and utilization of citrate were considered to be fairly reliable properties, although not shared by all the strains. Because of their variability, the remaining characteristics listed in Table 2 were not included in the pattern of reactions of the species. A comparison (Table 2) of the properties of $N$. dassonvillei with those of Streptomyces griseus (Gordon \& Horan, 1967) discloses that the two taxa are differentiated only by growth at $10^{\circ}$, hydrolysis of hippurate, acid formation from lactose and the form of their DAP.

Table 3. Some criteria for identifying six species of Nocardia

Property

Acid-fastness

Decomposition of Adenine

Casein

Hypoxanthine

Tyrosine

Urea

Xanthine

Growth at

$45^{\circ}$

Survival at $50^{\circ}$ for $8 \mathrm{hr}$

Nitrite from nitrate

Utilization of

Citrate

Malate

Succinate

Resistance to lysozyme

Hydrolysis of

Aesculin

Hippurate

Starch

Acid from

Adonitol

Arabinose

Dulcitol

Erythritol

Galactose

Glucose

Inositol

Lactose

Maltose

Mannitol

Mannose

Melibiose

$\alpha$-Methyl-D-glucoside

Raffinose

Rhamnose

Sorbitol

Xylose

\begin{tabular}{cccccc}
$\begin{array}{c}\text { N. aster- } \\
\text { oides }\end{array}$ & $\begin{array}{c}N . \\
\text { caviae }\end{array}$ & $\begin{array}{c}\text { N. brasi- } \\
\text { liensis }\end{array}$ & $\begin{array}{c}N . \\
\text { madurae }\end{array}$ & $\begin{array}{c}\text { N.pelle- } \\
\text { tieri }\end{array}$ & $\begin{array}{c}\text { N.dasson- } \\
\text { villei }\end{array}$ \\
(137 & $(24$ & $(62$ & $(44$ & $(15$ & $(26$ \\
strains) & strains) & strains) & strains) & strains) & strains) \\
& & \multicolumn{2}{l}{ Positive strains (\%) } & &
\end{tabular}

\begin{tabular}{rrrrrr}
\hline 55 & 66 & 80 & 0 & 0 & 0 \\
0 & 4 & 3 & 0 & 0 & 100 \\
0 & 0 & 98 & 100 & 100 & 100 \\
4 & 100 & 94 & 100 & 100 & 100 \\
1 & 0 & 100 & 86 & 100 & 100 \\
96 & 92 & 100 & 0 & 0 & 35 \\
0 & 100 & 0 & 0 & 0 & 100 \\
& & & & \\
41 & 50 & 2 & 36 & 13 & 0 \\
15 & 13 & 37 & 0 & 67 & 0 \\
94 & 88 & 0 & 100 & 100 & 92 \\
86 & 100 & 90 & 100 & 100 & 92 \\
& & & & & \\
38 & 29 & 98 & 80 & 7 & 96 \\
97 & 100 & 100 & 84 & 53 & 100 \\
92 & 100 & 100 & 80 & 0 & 100 \\
100 & 100 & 100 & 5 & 0 & 0 \\
& & & & & \\
$100 *$ & 100 & $100 *$ & 100 & 0 & 12 \\
\hline 6 & - & - & 2 & 0 & 100 \\
67 & 54 & 55 & 100 & 13 & 100 \\
0 & 0 & 0 & 91 & 0 & 0 \\
0 & 4 & 0 & 100 & 0 & 60 \\
0 & 0 & 0 & 0 & 0 & 0 \\
7 & 0 & 2 & 0 & 0 & 0 \\
27 & 0 & 94 & 81 & 7 & 62 \\
98 & 100 & 97 & 100 & 100 & 100 \\
3 & 100 & 100 & 61 & 0 & 0 \\
0 & 0 & 0 & 55 & 0 & 0 \\
6 & 18 & 4 & 32 & 0 & 100 \\
1 & 90 & 94 & 100 & 7 & 100 \\
17 & 36 & 68 & 61 & 0 & 100 \\
\hline 0 & 0 & - & 0 & 0 & $3 \mathbf{1}$ \\
0 & 0 & 0 & 0 & 0 & 23 \\
0 & 0 & 0 & 0 & 0 & 0 \\
32 & 5 & 0 & 100 & 0 & 65 \\
0 & 0 & 0 & 0 & 0 & 0 \\
0 & 5 & 0 & 100 & 0 & 81
\end{tabular}

* Fifty strains examined. 
The pattern of reactions that seems distinctive for Nocardia dassonvillei and separates the species from the other species represented in our collection was compared (Table 3) with the same reactions of five other species of Nocardia (Gordon, 1966). The following combination of characteristics sets the strains of $N$. dassonvillei apart from the strains of $N$. asteroides, $N$. caviae, $N$. brasiliensis, $N$. madurae and $N$. pelletieri: lack of acid-fastness; decomposition of adenine, casein, hypoxanthine, tyrosine, and xanthine; survival at $50^{\circ}$ for $8 \mathrm{hr}$; utilization of citrate and succinate; hydrolysis of hippurate; sensitivity to lysozyme; acid production from maltose, mannitol, and mannose; no acid from adonitol or inositol. Inability to hydrolyse aesculin was a somewhat less dependable property.

\section{DISCUSSION}

The original strains of Nocardia dassonvillei, named Streptothrix dassonvillei by Brocq-Rousseu (i907), were isolated from mildewed grain and fodder. Two years later, Liégard \& Landrieu (I9II) isolated a strain from a case of ocular conjunctivitis. They concluded that this strain was the same as Brocq-Rousseu's $S$. dassonvillei and suggested its assignment to the genus Nocardia. Accounts by Brumpt (1913) Forbes (I924) and Langeron (I922) are the only reports we have found in the literature of other strains named $N$. dassonvillei. Actinomyces listeri, described by Erikson (1935) and transferred to the genus Streptomyces by Waksman \& Henrici (I948), is considered in the synonymy of $N$. dassonvillei.

The distribution of the first strains of Nocardia dassonvillei is repeated in the histories of the strains listed in Table I. Nine of the 26 strains came from soil, and I 5 were described as isolations from human or animal infections. Although pathogenicity is outside the scope of our studies, we are tempted to speculate on the discarding in medical laboratories of cultures of $N$. dassonvillei as contaminants because of their macroscopic resemblance to cultures of Streptomyces griseus.

With allowance for microbial variation, the combination of 32 properties given here is believed to be a reliable basis for differentiating strains of Nocardia dassonvillei from the other strains of aerial hyphae-forming nocardias and streptomycetes in our collection. We cannot, however, suggest a combination of a few properties as a presumptive test for the recognition of $N$. dassonvillei. Among the properties of the six species of nocardias in Table 3 , the decomposition of adenine is useful for separating $N$. dassonvillei from the other five species and, if the nocardias were limited to six species, could be proposed as a presumptive test for $N$.dassonvillei. The genus Nocardia, however, is not so obligingly simple.

This study was supported in part by research grant AI-06276 from the Public Health Service, Bethesda, Maryland, U.S.A., and by research grant GB-2579 from the National Science Foundation, Washington, D.C., U.S.A. The authors greatly appreciate this assistance and that of the investigators who sent us their strains. They also gratefully acknowledge a Biomedical Science Support Grant from the Public Health Service for the preparation of Plate 2. 


\section{REFERENCES}

Becker, B., Lechevalier, M. P., Gordon, R. E. \& Lechevalier, H. A. (1964). Rapid differentiation between Nocardia and Streptomyces by paper chromatography of whole-cell hydrolysates. Appl. Microbiol. 12, 421 .

BrocQ-Rousseu, D. (1907). Recherches sur les altérations des grains des céréales, et des fourrages. Thèses présentées a la faculté des sciences de Paris, p. 9. Nancy: Imprimeries Réunies.

Brumpt, E. (1913). Précis de Parasitologie, 2nd ed., p. 976. Paris: Masson et Cie.

ERIKSON, D. (I935). The pathogenic aerobic organisms of the actinomyces group. Spec. Rep. Ser. med. Res. Council 203, 5 .

Forbes, J. G. (1924). The atmosphere of the underground electric railways of London. A study of its bacterial content in 1920. J. Hyg., Camb. 22, 123.

Gerber, N.N. (1966). Phenazines and phenoxazinones from some novel Nocardiaceae. Biochemistry 5, 3824 .

GoRDon, R. E. (1966). Some criteria for the recognition of Nocardia madurae (Vincent) Blanchard. J. gen. Microbiol. 45, 355.

Gordon, R. E. (1967). The taxonomy of soil bacteria. In The Ecology of Soil Bacteria. Ed. by T. R. G. Gray and B. Parkinson. Liverpool University Press. (In the Press.)

Gordon, R. E. \& Horan, A. C. (I968). A piecemeal description of Streptomyces griseus (Krainsky) Waksman \& Henrici. J. gen. Microbiol. 5o, 223.

Langeron: M. (1922). Les oospores. In Noveau Traité de Médecine, Fasc. 4, p. 430. Ed. by G.-H. Roger, F. Widal and P.-J. Teissier. Paris: Masson et Cie.

LiÉGard, H. \& LANDrieu, M. (I9I I). Un cas de mycose conjonctivale. Ann. Oculist. 146, 4I8.

WAKSMAN, S. A. \& HeInRICI, A. T. (1948). In Bergey's Manual of Determinative Bacteriology, 6th ed. Ed. by R. S. Breed, E. G. D. Murray and A. P. Hitchens. p. 96r. Baltimore: Williams and Wilkins Co.

\section{EXPLANATION OF PLATES}

Plate I

Aerial hyphae of Nocardia dassonvillei, strain 794, on yeast dextrose agar after Io days of incubation at $28^{\circ}$.

\section{Plate 2}

Growth of cultures of Nocardia dassonvillei and Streptomyces griseus on slants of yeast dextrose agar after 14 days of incubation at $28^{\circ}$. 


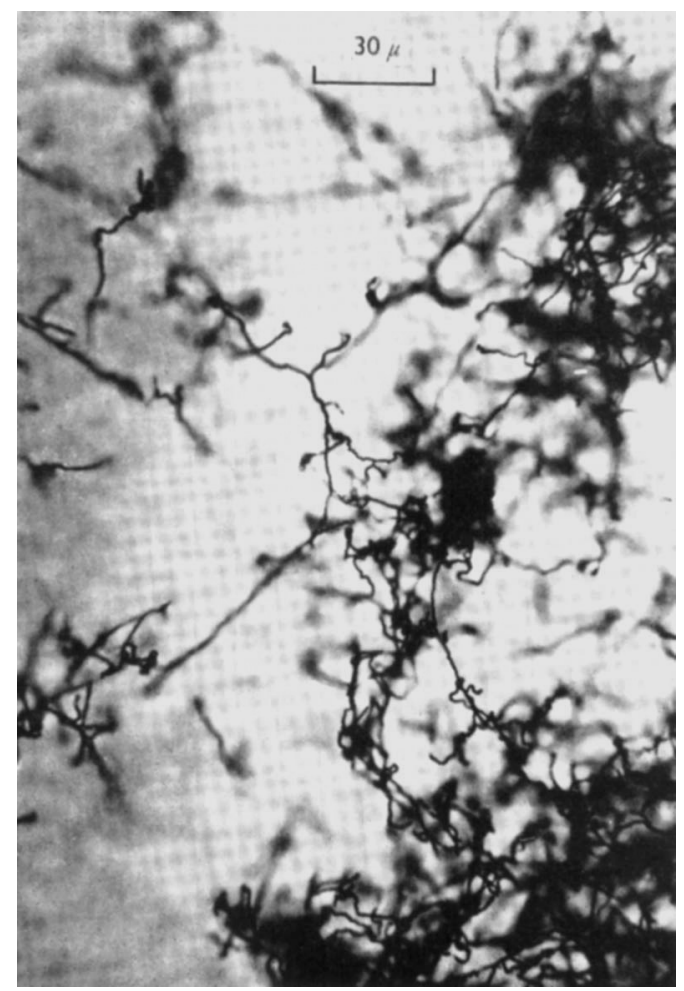


Journal of General Microbiology, Vol. 50, No. 2

PLATE 2
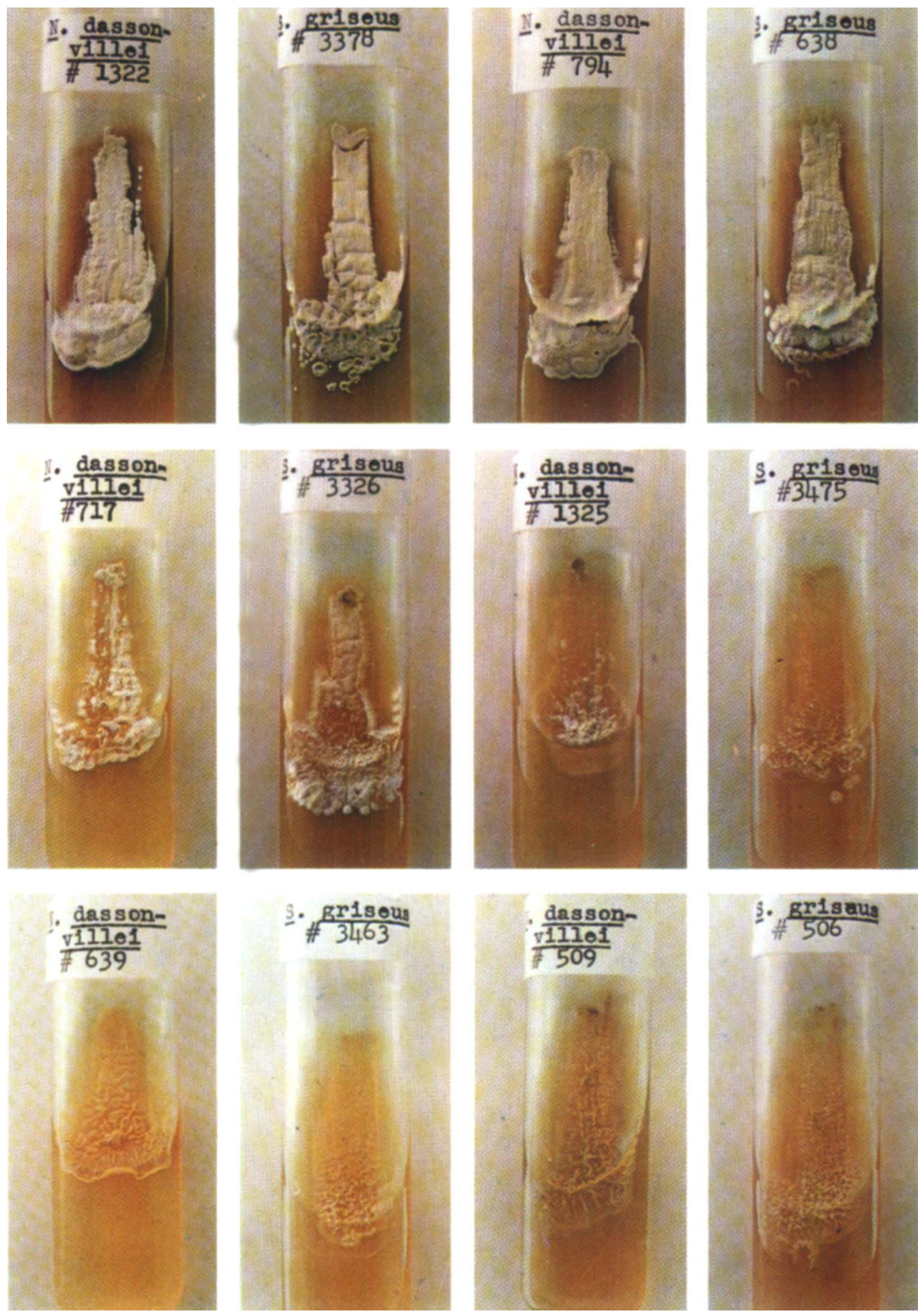

R. E. GORDON AND A. C. HORAN 